\title{
Development of Student Worksheet Based Guided Inquiry to Practice Scientific Literacy in Thermochemical Chapter of XI Grade in Senior High School
}

\author{
Filayati Ma'ruf Nur, Rusly Hidayah* \\ Chemistry Education, College Student, \\ State University of Surabaya \\ Surabaya, Indonesia \\ ruslyhidayah@gmail.com
}

\begin{abstract}
The purpose of this study is development the Student Worksheet based on theoretical and empirical feasibility. The theoretical feasibility of the Student Worksheet is based on the feasibility of the content, language, presentation and graphics. The empirical feasibility of the Student Worksheet is reviewed based on tests of scientific literacy skills and student responses. The research technique used in this study is descriptive quantitative and the research design uses one group pretest-posttest design. The research procedure used the method of Research and Development ( $R$ \& $D)$ by Sukmadinata (2012). Student Worksheets based guided inquiry to practice scientific literacy skills in the thermochemical chapter. The development of the Student Worksheet was declared suitable for use as teaching material in accordance with the theoretical feasibility of $86 \%$ content eligibility categorized as very feasible, linguistic feasibility with a percentage of $80.67 \%$ categorized as feasible, presentation eligibility with a percentage of $83.33 \%$ categorized very feasible, and graphic feasibility with a percentage of $87.23 \%$ is categorized as very feasible. The development Student Worksheet gets a positive response from students with an average percentage of $89.33 \%$ which is categorized as responding strongly. The average result of pretest of scientific literacy ability is $\mathbf{5 0 . 3 7}$ which is stated not to reach the minimum completeness criteria and the average posttest results of scientific literacy ability of 87.90 has reached the minimum completeness criteria. As well as scientific literacy test results obtain an average $\mathrm{N}$-Gain of 0.77 in the high category.
\end{abstract}

Keywords - Student Worksheet, Guided Inquiry, Scientific Literacy, Thermochemical.

\section{INTRODUCTION}

Education has an important role in creating a quality future generation for the country's future. The 2013 curriculum strongly encourages students to be active in the learning process so that students can develop and understand concepts related to the subjects they are experiencing. Subjects that involve the activeness of students one of them is about science. Chemistry is a part of science that can be a place for students to learn about nature, and can develop further in the matter of its application in accordance with the content of daily life in the present and future.

Thermochemistry is one of the chemistry studies that study the heat changes that accompany chemical reactions [3]. Students often assume that the chemistry taught at school have been a separate lesson from their daily lives. As students, scientific knowledge is needed to deal with important issues involving science and technology. Students need to be equipped with the ability to care, be responsive, critical, and creative to solve these problems. This can be achieved if students have scientific literacy.

Scientific literacy is the ability to engage with sciencerelated issues, and with the ideas of science, as a reflective citizen. Scientific literacy not only requires knowledge in the form of scientific concepts and theories, but also knowledge of general procedures relating to scientific inquiry and how science is developed. Scientific literacy consists of aspects context, scientific knowledge, scientific competence, and scientific attitudes. Aspect context includes personal, local and national, and global situations. Aspect scientific knowledge includes content, procedural, and epistemic knowledge. Aspect scientific competence includes explain phenomena scientifically, evaluate and design scientific investigations, and interpret data and evidence scientifically. Aspect scientific attitudes include interest in science, valuing scientific approaches to inquiry, and environmental awareness. Indonesia participated in PISA from 2000 to 2015. The results of the international comparative study of PISA (Program for International Student Assessment) held by the OECD (Organization for Economic Cooperation and Development) in 2015 showed that Indonesian students obtained scientific literacy scores below the average of 403, while the 2015 PISA scientific literacy average score was 493 [8].

Permendikbud No. 22 of 2016 states that to strengthen the scientific approach, it is necessary to apply inquiry 
learning [4]. With inquiry learning the students can describe objects and phenomena, ask questions, build hypotheses, test hypotheses against existing scientific knowledge, and communicate their ideas to others [1]. Therefore, students can be active in, develop their scientific knowledge with their reasoning and critical thinking skills so that they are able to solve problems or issues that exist in everyday life based on evidence from facts obtained or theoretical explanations. According to Sanjaya (2014) the inquiry learning model emphasizes on developing balanced cognitive, affective, and psychomotor aspects so that learning through this model is considered meaningful [10]. Therefore, a forum is needed for students to improve their scientific literacy skill through guided inquiry-based teaching materials.

A forum to practice students' scientific literacy can be done by associate the content learned in school to the context related to that content through the development of teaching materials. One that includes teaching materials is the Student Worksheet. Based on a study conducted by Nadia (2016) shows that $15.84 \%$ of students understand the usefulness of the material that has been studied in school in daily life, and $36.84 \%$ of students use Student Worksheet in learning chemistry [12]. Reka (2016) states that Student Worksheet based guided inquiry is suitable for use as teaching material in class [2]. Based on the interview with the chemistry teacher at SMA Negeri 1 Taman that learning process in schools using Student Worksheet from outside publishers that contain a summary of the material and exercises so that is lack to practice scientific literacy of students. Therefore, there is a need for research to develop Student Worksheet based guided inquiry in hopes of training students' scientific literacy on thermochemical materials so that their learning outcomes can improve.

\section{METHODS}

The type of research used is Research and Development ( $R$ \& D) by Sukmadinata (2012) and is limited to the preliminary study phase, development study phase (limited trial), and the testing phase [11]. The study was conducted at Taman 1 Senior High School class XI science with the subjects being tested as many as fifteen students who were chosen heterogeneously based on their academic level.

This study uses several instruments that is study sheet, validation sheet, response questionnaire sheet, scientific literacy test sheet and supported by student activity observation sheets. The research method used is study method, validation method, questionnaire method, and scientific literacy test method.

Analysis of the results data has served to provide an explanation based on the advice of experts. Validation method serves to provide value to Student Worksheet theoretical eligibility criteria. The questionnaire method serves to determine the response of students after using the developed Student Worksheet. Scientific literacy test method to determine the scientific literacy skills of students before and after using the developed Student Worksheet.

Data processing results of validation using a Likert scale consisting of a score range of 1-5 [9]. Validation results are used to determine the theoretical feasibility of Student
Worksheet which is developed and interpreted in the form of percentages as follows:

TABLE I. INTERPRETATION CRITERIA SCORE

\begin{tabular}{|c|c|}
\hline Value & Criteria \\
\hline $0-20$ & Not Feasible \\
\hline $21-40$ & Less Feasible \\
\hline $41-60$ & Quite Feasible \\
\hline $61-80$ & Feasible \\
\hline $81-100$ & Very Feasible \\
\hline
\end{tabular}

Based on the eligibility criteria, the developed Student Worksheet was declared feasible if it obtained a percentage of $\geq 61 \%$ [9].

The student response questionnaire consists of answers "Yes" (score 1) and "No" (Score 0) [9]. Data from the responses of students used to determine the empirical Student Worksheet feasibility developed was measured using the following equation:

$$
\text { Response (\%) }=\frac{\text { Tatal Scare }}{\text { Total Maxmum Scome }} \times 100 \%
$$

Assessment of scientific literacy tests uses a scale of 0100 using the following equation:

$$
\text { Value }=\frac{\text { zoare Obtamed }}{\text { Maximnum Scare }} \times 100
$$

Scientific literacy skills of students are categorized as good if they get a score of $\geq 78$, that is, at least they have reached the minimum completeness and are skilled if they have a gain value of $\geq 0.3$ with the medium category obtained by the following formula:

$$
\text { Gain Score }=\frac{\$ \% \text { pastiest }-\% \text { protest }}{100 \%-\% \text { pretest }}
$$

Empirical feasibility supporting data is observation data of student's activities during the trial using the developed Student Worksheet.

\section{RESULTS AND DISCUSSION}

This study aims to describe the feasibility of student worksheet based guided inquiry of XI grade in senior high school in thermochemical chapter reviewed based on theoretical and empirical feasibility.

\section{A. Theoretical Feasibility of Student Worksheet}

Student Worksheet developed is adjusted to the Student Worksheet structure according to the Ministry of National Education [6]. Student Worksheet reviewers developed were one chemistry lecturer. The purpose of the study was to provide advice on the Student Worksheet that was developed so that improvements could be made.

Student Worksheet's theoretical feasibility is based on the results of Student Worksheet validation covering several eligibility criteria, that is content, linguistic, presentation and graphic eligibility. Validation was carried out by two chemistry lecturers and one chemistry teacher. Student Worksheet is declared feasible if each feasibility criterion gets $\geq 61 \%$ [9]. Student Worksheet validation results data are as follows: 
TABLE II. VALIDATION RESULTS

\begin{tabular}{|c|l|c|c|}
\hline No & \multicolumn{1}{|c|}{ Aspect Assessed } & Percentage & Categories \\
\hline 1. & Content feasibility & $86 \%$ & $\begin{array}{c}\text { Very } \\
\text { Feasible }\end{array}$ \\
\hline 2. & $\begin{array}{l}\text { Linguistic } \\
\text { feasibility }\end{array}$ & $80.67 \%$ & Feasible \\
\hline 3. & $\begin{array}{l}\text { Presentation } \\
\text { feasibility }\end{array}$ & $83.33 \%$ & $\begin{array}{c}\text { Very } \\
\text { Feasible }\end{array}$ \\
\hline 4. & Graphic feasibility & $87.23 \%$ & $\begin{array}{c}\text { Very } \\
\text { Feasible }\end{array}$ \\
\hline
\end{tabular}

The validation results above show that the Student Worksheet developed in each aspect is categorized as feasible because the value obtained is $\geq 61 \%$ [9]. The aspect of content feasibility to determine the suitability of Student Worksheet which is related to the feasibility of Student Worksheet content and obtain a percentage of $86 \%$ which is categorized as very feasible. The aspect of linguistic feasibility to determine the suitability of Student Worksheet that relate to Student Worksheet linguistic feasibility and obtain a percentage of $80.67 \%$ which is categorized as feasible. The aspect of presentation feasibility to determine the suitability of Student Worksheet which is related to the feasibility of presenting Student Worksheet and obtain a percentage of $83.33 \%$ which is categorized as very feasible. The aspect of graphic feasibility is to determine the suitability of Student Worksheet which is related to the feasibility of Student Worksheet graphics and obtain a percentage of $87.23 \%$ which is categorized as very feasible.

\section{B. Empirical Feasibility of Student Worksheet}

\section{1) Scientific literacy test results}

Scientific literacy tests to determine students' scientific literacy skills and achievement of learning objectives developed through pretest and posttest. Pretest was given to students before using the developed Student Worksheet, while the posttest was given after using Student Worksheet which was developed to find out the comparison of student learning outcomes between before and after using the Student Worksheet developed and how much the increase was.

Improved scientific literacy test results were analyzed using the normalized Gain value criteria. Scientific literacy skills of students are declared parcticed if they get N-Gain $>$ 0.3 in the medium category. The results of pretest and posttest were analyzed using SPSS and the KolmogrovSminov $\mathrm{Z}$ pretest value was $0.702>0.05$ with the most extreme differences positive $0.181>0.05$. While the kolmogrov-sminov $\mathrm{Z}$ posttest value is $0.646>0.05$ with the most extreme differences positive value $0.167>0.05$. Based on the results of the analysis, the pretest and posttest data obtained were normally distributed.

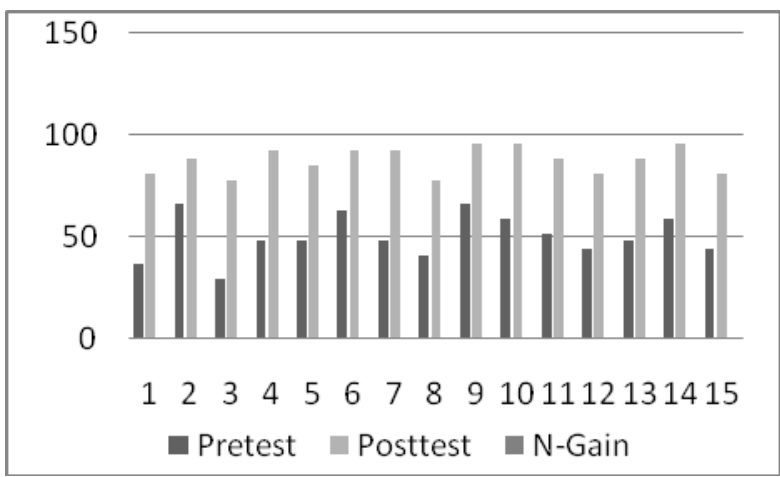

\section{FIGURE I SCIENTIFIC LITERACY TEST RESULTS}

Based on the results of the pretest of scientific literacy it can be seen that before using Student Worksheet developed in the process of learning the level of scientific literacy skill of students in the low category with an average score of 50.37 and declared to have not reached the minimum completeness criteria set by the school which is 78 . While the results of posttest scientific literacy after using Student Worksheet developed in the learning process, the level of scientific literacy skill of students has increased with an average posttest result of 87.90. The Gain value of scientific literacy skill of students has increased by 0.77 which is categorized as high. This shows that the developed Student Worksheet can be said to be empirically feasible because it can practice student's scientific literacy skills.

\section{2) The results of student's responses}

The developed Student Worksheet is declared empirically feasible if the responses of students get a percentage of $\geq 61 \%$ [9]. Questionnaire responses of students are given after the learning process using the developed Student Worksheet.

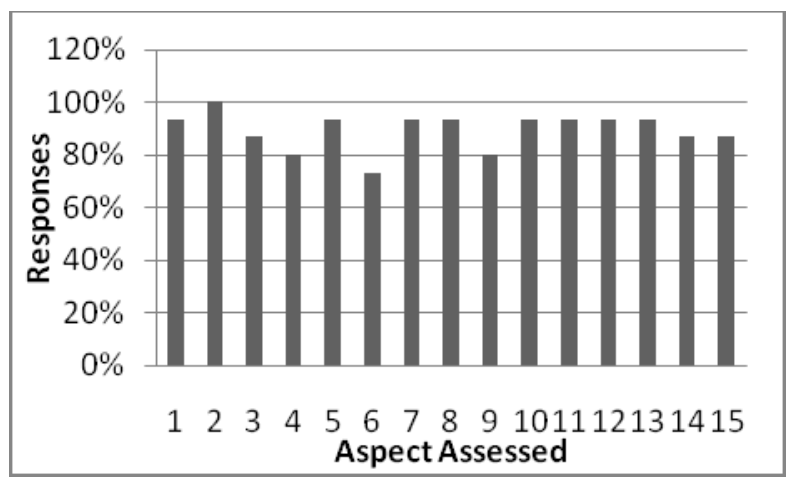

FIGURE II STUDENT RESPONSE RESULTS

Based on the picture above, the average score of the student's responses is $88.88 \%$, so it can be stated that the students are very responsive or can be described as empirically feasible supported by the observation data of student's activities.

\section{Conclussions}

Based on the results and discussion of the study, it can be concluded that the Student Worksheet based guided inquiry in thermochemical chapter that has been developed has been feasible to be used as teaching material because it 
has reached and fulfilled all the eligibility criteria, namely as follows :

\section{1) Theoretical feasibility}

The Student Worksheet based Guided inquiry to practice scientific literacy are declared feasible to use based on content, linguistic, presentation and graphic feasibility with percentages of $86 \%, 80.67 \%, 83.33 \%$ and $87.23 \%$ respectively.

\section{2) Empirical feasibility}

Empirical feasibility of Student Worksheet based Guided inquiry in terms of the results of scientific literacy tests and student responses. The results of scientific literacy tests for each individual experience an increase and classically NGain is 0.77 in the high category. The Student Worksheet based Guided inquiry are appropriate to be used to train scientific literacy in terms of the responses of students to an average percentage of $89.33 \%$ with highly responding categories.

\section{ACKNOWLEDGMENT}

Thank you to all parties who involved in conducting this research.

\section{REFERENCES}

[1] Anam, Khoirul. Inquiry Based Learning: Methods and Applications. Yogyakarta: Student Literature, 2015.
[2] Anggraeni, Reka Ayu and Hidayah, Rusly. Development of guided inquiry-based simple chemistry practicum student activity sheets for class XI. Unesa Journal of Chemical Education, 2016, Vol.5 (2): pp 233-238.

[3] Chang, Raymond. Basic Chemistry: Core Concepts, 3rd Edition 2. Jakarta: Erlangga, 2005.

[4] Ministry of Education and Culture. Minister of Education and Culture Regulation Number 22 of 2016 concerning the Standard Process for Primary and Secondary Education. Jakarta: Ministry of Education and Culture, 2016.

[5] Ministry of Education and Culture. Minister of Education and Culture Regulation Number 23 of 2016 concerning Educational Assessment Standards. Jakarta: Ministry of Education and Culture, 2016.

[6] Ministry of National Education. Guide to the Development of Teaching Materials. Jakarta: Directorate General of Basic and Secondary Education Management, 2008

[7] Hake, R.R. 1999. Analizing Change/Gain Scores. (On line). Available at http://www.physics.indiana.edu/ sdi/AnalizingChange-Gain.pdf. Accessed on May 18, 2017.

[8] OECD. PISA 2015 Assessment and Analytical Framework: Science, Reading, Mathematic, and Financial Literacy. Paris: OECD Publishing, 2016.

[9] Riduwan. Research Variables Measurement Scale. Bandung: Alfabeta, 2015.

[10] Sanjaya, Vienna. Education Process Oriented Learning Strategies. Jakarta: Kencana, 2013.

[11] Sukmadinata, Nana Syaodih. Educational Research Methods. Bandung: PT. Remaja Rosdakarya, 2016.

[12] Vienurillah, Nadia and Dwiningsih, Kusumawati. Development of Student Activity Oriented Sheets (LKS) on Submaterials Factors Affecting the Rate of Reaction. Unesa Journal of Chemical Education, 2016, Vol.5 (2): pp 428-433. 